\title{
Anaerobic bacteria isolated from the alimentary canals of alfalfa leafcutting bee larvae
}

\author{
G. Douglas Inglis*,**, L. Jay Yanke, Mark S. Goettel \\ Agriculture and Agri-Food Canada Research Centre, P.O. Box 3000, \\ Lethbridge, AB, T1J 4B1, Canada
}

(Received 2 January 1998; accepted 13 March 1998)

\begin{abstract}
Microorganisms were isolated from the alimentary canals of third-instar alfalfa leafcutting bee (Megachile rotundata) larvae under strict anaerobic conditions. In all 3 years of the study, small populations ( 8.0 colony-forming units per gut) of a limited number of bacterial taxa (primarily the facultatively anaerobic bacteria Paenibacillus macerans, Bacillus licheniformis, B. brevis, $B$. mycoides and $P$. polymyxa) were isolated. With the exception of three isolates of Clostridium longisporum recovered in 1993, no obligate anaerobic bacteria were isolated. The small size of populations and the inconsistency of recovery of bacteria in different years suggest that anaerobic microorganisms are not common inhabitants of leafcutting bee larval guts. Consequently they could not have a significant impact on the ecology of the alimentary canal nor influence the development of chalkbrood disease caused by the entompathogenic fungus, Ascosphaera aggregata. (C) Inra/DIB/AGIB/Elsevier, Paris
\end{abstract}

Megachile rotundata / larvae / alimentary canals / anaerobic microflora

\section{INTRODUCTION}

Alfalfa leafcutting bees (Megachile rotundata Fabricius) are the principal pollinators used for production of seed alfalfa (Medicago sativa) in northwestern North America. Chalkbrood, caused by the ascomycetous fungus, Ascosphaera aggregata has become an increasingly important disease of leafcutting bees throughout this area, and bee losses can exceed $50 \%$. Disease is initiated by ascospores in food provisions that are ingested by early-instar leafcutting bee larvae. The ascospores, putatively stimulated by an elevated $\mathrm{CO}_{2}$ concentration, germinate in the mid-gut, and hyphae then penetrate into the hemocoel eventually causing death of the larvae $[12,15]$.

\footnotetext{
* Correspondence and reprints

** Present address: Department of Entomology and Plant Pathology, Mississipi State, MS 397629775 , USA
} 
The gut microflorae of insects can be antagonistic to pathogens and affect the epizootiology of disease (e.g. [3, 7]). Although a number of bacteria and fungi were isolated from leafcutting bee larval guts [10], these microorganisms did not inhibit chalkbrood [11]. Leafcutting bee larvae have a blind gut (no anus) up to the fourth-larval instar [17], and low redox potential of the midgut [16] indicates a low oxygen environment. Although a number of facultative anaerobic bacteria and fungi were previously isolated from larval guts under aerobic conditions [10], the prevalence and diversity of obligate anaerobic and facultative aerobic microorganisms in the alimentary canals of alfalfa leafcutting bee larvae have not been investigated. To ascertain if anaerobic microorganisms could have an impact on the ecology of the larval guts, the objective of this study was to isolate, under strict anaerobic conditions, microorganisms from the guts of third-instar larvae over a 3-year period.

\section{MATERIALS AND METHODS}

Leafcutting bee cells were collected on 19 August 1993, 18 July 1994, 3 August 1994 and 25 July 1996 from nests in bee shelters situated in an irrigated field of alfalfa at the Agriculture and Agri-Food Canada Research Centre at Lethbridge. The cells were immediately transported to the laboratory where ten arbitrarily selected predefecation larvae (third instar) were removed and surface-sterilized in $1 \%$ sodium hypochlorite with $0.1 \%$ Tween 80 for $2 \mathrm{~min}$, followed by two rinses in sterile distilled water. Surfacesterilized larvae were stored for a maximum of $12 \mathrm{~h}$ at $5^{\circ} \mathrm{C}$, warmed to room temperature, and placed in an anaerobic chamber $(90: 10 \%$ $\mathrm{CO}_{2}: \mathrm{H}_{2}$; Forma-Scientific, Anaerobic System, Model 1024). Alimentary canals were removed from each larva by making a longitudinal incision and carefully extracting the intact gut in sterile saline $(0.85 \%$ sodium chloride). The digestive tracts were individually homogenized in $1 \mathrm{~mL}$ of Bryant's anaerobic dilution solution [2] using a Kontes micropestle, and $200 \mu \mathrm{L}$ of the homogenate were spread in duplicate on modified Dehority's agar (MD agar) [1]; this medium has been shown to support the growth of a variety of anaerobic bacteria (Yanke et al., unpublished).

In 1993, but not in 1994 or 1996, the media were amended with $50 \mathrm{mg} \mathrm{L}^{-1}$ Nystatin (Sigma, St. Louis, MI) to inhibit fungi or $100 \mathrm{mg} \mathrm{L}^{-1}$ Tetracycline (Sigma, St. Louis, MI) to inhibit bacteria, and all cultures were incubated in the anaerobic chamber. Cultures were initially placed at $30^{\circ} \mathrm{C}$ in 1993 , but no fungal and only a few bacterial colonies were observed by 11 days. Cultures were subsequently transferred to $37^{\circ} \mathrm{C}$ for an additional 8 days. In 1994 and 1996, the cultures were immediately placed at $37^{\circ} \mathrm{C}$, and colony-forming units (CFU) were counted and colonies collected after 5 days. To isolate cellulolytic bacteria, the homogenate was placed in tubes of MD broth containing $1-\mathrm{cm}^{2}$ pieces of Whatman \#1 filter paper as the carbohydrate source [1]. From tubes displaying filter paper degradation, the medium was serially diluted in a 10 -fold dilution series, and $200 \mu \mathrm{L}$ from each dilution was spread onto MD agar. Isolates were streaked for purity and placed in MD broth containing filter paper to confirm cellulolytic activity. Collected bacteria were stored in $10 \%$ glycerol at $-80^{\circ} \mathrm{C}$ until characterized.

Catalase, oxidase and gram stain reactions were determined for bacteria grown on MD agar for $24 \mathrm{~h}$ using standard methods, and all isolates were also tested for growth in ambient oxygen. Bacteria were identified by gas-liquid chromatography of fatty acid methyl esters using the MIDI Microbial Identification System (MIDI Inc., Newark, DE). To accomplish this, bacteria were grown aerobically on trypticase soy agar (Difco, Detroit, MI) at $37^{\circ} \mathrm{C}$ for $24 \mathrm{~h}$ and fatty acids extracted and methylated according to the MIDI protocol [14]. Bacillus and Paenibacillus species were further characterized using the API CH50B (Biomerieux, St. Laurent, Quebec) identification system [13].

In 1996, alimentary canals from six arbitrarily selected third-instar larvae were excised, fixed in $2 \%$ glutaraldehyde in $0.05 \mathrm{M}$ phosphate buffer, post-fixed with $1 \%$ osmium tetroxide, dehydrated in ethanol, critical-point dried in liquid $\mathrm{CO}_{2}$, sputter coated with gold, and examined with a Hitachi S-570 scanning electron microscope (SEM) at an accelerating voltage of $10 \mathrm{kV}$.

\section{RESULTS AND DISCUSSION}

Small populations of anaerobic bacteria with a limited diversity (five taxa per year) 
were recovered from the alimentary canals of pre-defecation leafcutting bee larvae in $1994(=8.0 \mathrm{CFU} / \mathrm{gut})$ and $1996(=2.5$ CFU/gut). Large numbers of pollen grains were observed in guts of all six larvae examined with the SEM. Alfalfa leafcutting bee provisions are comprised of water, nectar and pollen with $M$. sativa pollen being the most prevalent taxon [8]. Although bacterial cells were infrequently observed, in several instances aggregations of bacilli were observed on the surfaces of pollen grains or on the peritrophic membrane (figures 1-4). In both 1994 and 1996, Paenibacillus macerans (comprising $24-45 \%$ of the total iso- lates recovered) and Bacillus licheniformis (24-60\%) were the most common taxa isolated. Bacillus brevis, B. mycoides and $P$. polymyxa were recovered at lower frequencies $(\geq 15 \%)$. Only bacilli were observed in the alimentary canals of larvae examined with the SEM in 1996; two cell morphologies were observed and included short robust rods $(0.8-1.1 \times 0.5-0.7 \mu$; figures $I$ and 2 ) and longer bacilli (2.2-3.0 $\times 0.5-0.7 \mu$; figures 3 and 4 ). In 1993, 23 additional bacterial isolates grew after the incubation temperature was raised from 30 to $37^{\circ} \mathrm{C}$ (32 total bacteria); 29 were Bacillus spp. with three cellulolytic isolates iden-

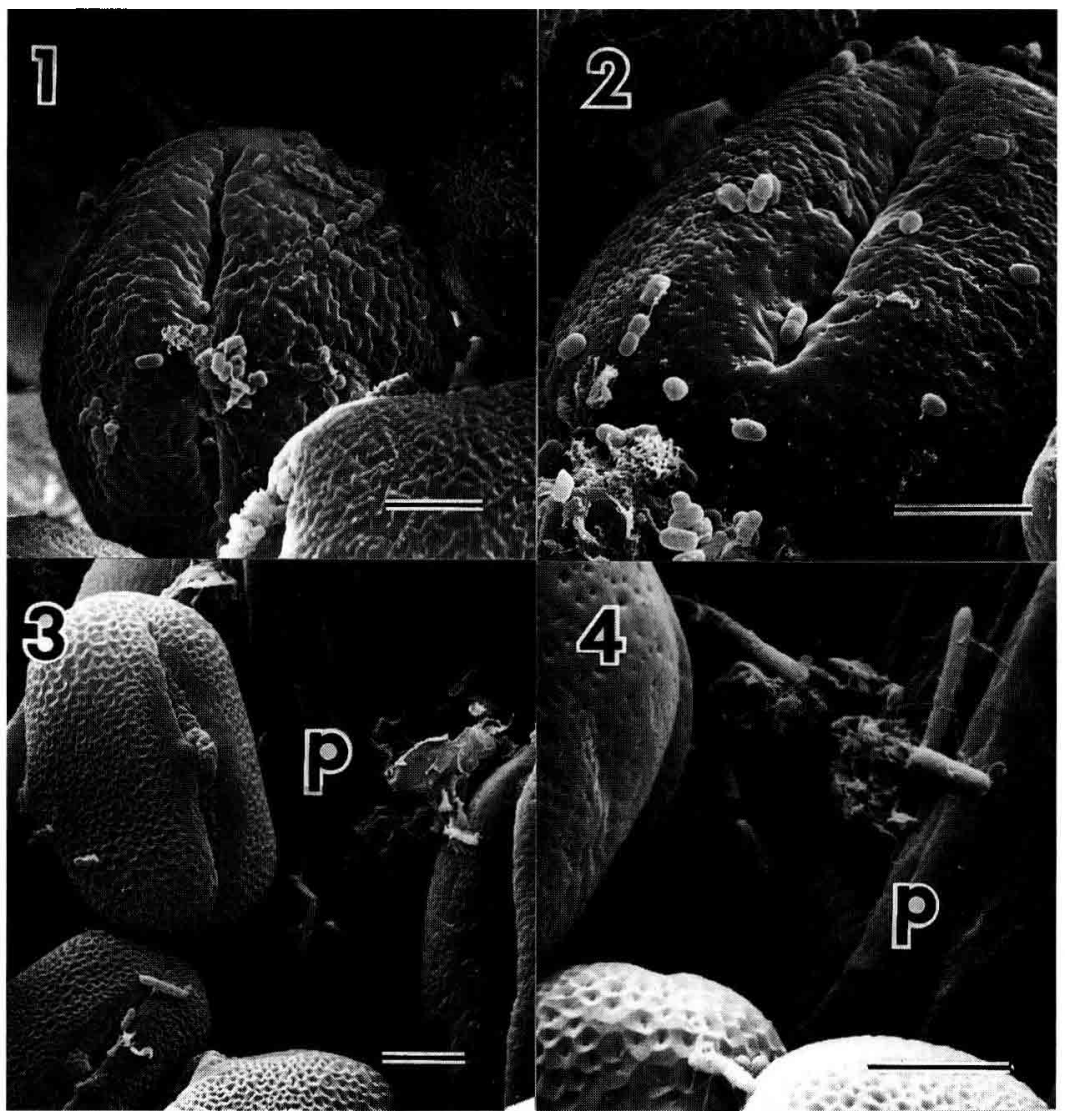

Figures 1-4. Scanning electron micrographs of bacilli in the alimentary canals of third-instar larvae of alfalfa leafcutting bees (Megachile rotundata) collected in 1996. 1 and 2) Bacilli on the surface of pollen grains. 3 and 4) Bacilli on pollen grains or on the peritrophic membrane $(p)$. Bar $=5 \mu \mathrm{m}$. 
tified as Clostridium longisporum. No cellulolytic bacteria were isolated from larval guts in 1994 or 1996.

All of the Bacillus and Paenibacillus species we isolated from larval guts are cosmopolitan and are categorized as facultative anaerobes [6]. Three of the taxa, B. brevis, $B$. licheniformis and $P$. macerans, have been previously isolated from leafcutting and honey bee guts under aerobic conditions $[5,10]$. An actinomycete-like bacterium was also consistently recovered from larval guts in $1994(6-24 \%, n=3-12)$. Actinomycetes, primarily the obligate aerobe Streptomyces, have also been reported from the alimentary canals of leafcutting and honey bees under aerobic conditions $[4,10]$. The actinomycete-like bacterium that we isolated grew very poorly in both anaerobic and aerobic environments, produced white filamentous colonies, thin hyaline hyphae $(<2 \mu \mathrm{m}$ in diameter), but it did not sporulate in culture. We were unable to isolate or observe fungi, even though Trichosporonoidies megachiliensis, a facultative anaerobe, is commonly associated with leafcutting bee larval guts [9].

Despite having blind guts with redox potentials indicative of a low oxygen environment, we recovered only small populations of anaerobic bacteria with low taxonomic diversity from leafcutting bee larvae in three different years. The majority of bacteria isolated from larval guts under aerobic conditions are probably transients having been ingested during consumption of provisions and subsequently excreted in frass $[10,11]$. Our observations indicate that anaerobic bacteria isolated from alfalfa leafcutting bee larval guts are also transient. With the exception of Clostridium, the bacteria we isolated are facultative anaerobes, and many have been isolated previously from the alimentary canals of leafcutting bees under aerobic conditions [10]; Clostridium spores are cosmopolitan and can survive prolonged exposures to oxygen. Furthermore, many of the bacteria isolated in 1993 grew at $\geq 37^{\circ} \mathrm{C}$ but not at $30^{\circ} \mathrm{C}$. Nest temperatures are substantially less than $37^{\circ} \mathrm{C}$ for much of the day and night period, and microorganisms resident in the alimentary canal would be expected to grow at $30^{\circ} \mathrm{C}$. The results of this study indicate that anaerobic microorganisms are not abundant in alfalfa leafcutting bee larval guts, and therefore would not be expected to have a significant impact on the ecology of the alimentary canal or on the development of chalkbrood disease.

\section{ACKNOWLEDGMENTS}

We thank the following people at the Agriculture and Agri-Food Canada Research Centre at Lethbridge: Tim Myers and Grant Duke for collecting leafcutting bees in 1994; Byron Lee for conducting the SEM; and Dr Denis Gaudet and Dr Colin D'Silva for their comments on the manuscript. This manuscript is Lethbridge Research Centre contribution \#3879670.

Résumé - Bactéries anaérobies isolées du tube digestif des larves de la mégachile de la luzerne. La mégachile de la luzerne (Megachile rotundata Fabricius) est le principal pollinisateur utilisé dans le nord-ouest de l'Amérique du Nord pour la production de luzernes porte-graines (Medicago sativa). Ascosphaera aggregata Skou, l'agent du couvain plâtré, a acquis une importance de plus en plus grande en tant que parasite des mégachiles. Les ascospores sont ingérées par les larves, germent dans l'intestin moyen et le champignon pénètre dans l'hémocèle, pouvant provoquer la mort de la larve. Jusqu'au quatrième stade larvaire, la larve possède un tube digestif fermé et les potentiels redox montrent que l'environnement est pauvre en oxygène. Afin de déterminer si le tube digestif de la larve de troisième stade possède une microflore anaérobie, on a isolé, en conditions strictement anaérobies, des microorganismes à partir d'intestins larvaires excisés. Au cours des trois années qu'a duré l'expérience, on a isolé de petites popula- 
tions ( $\leq 8,0$ unités formant une colonie/intestin) d'un nombre restreint de taxons de bactéries (principalement les bactéries anaérobies facultatives Paenibacillus macerans, Bacillus licheniformis, B. brevis, B. mycoides et $P$. polymyxa). À l'exception de trois isolats de Clostridium longisporum trouvés en 1993 , aucune bactérie anaérobie obligée n'a été isolée. De rares bacilles ont été aussi observés sur le pollen et les membranes péritrophiques. La taille réduite des populations et la présence irrégulière des bactéries d'une année sur l'autre laisseraient penser que les microorganismes anaérobies ne sont pas des hôtes habituels des intestins de larves de mégachiles. Ils n'auraient donc pas un impact significatif sur l'écologie du tube digestif, ni une influence sur le développement du couvain plâtré. (C) Inra/DIB/AGIB/Elsevier, Paris

\section{Megachile rotundata / tube digestif / larve / microflore anaérobie}

\section{Zusammenfassung - Anaerobe Bakterien des Magendarmtrakts von Larven der Blattschneiderbiene (Megachile rotundata} Fabricius). Die Mikroorganismen der Blattschneiderbiene Megachile rotundata, die zur besseren Bestäubung der Luzerne gehalten wird, wurden untersucht. Aus dem Magendarmtrakt von Larven im dritten Stadium wurden unter vollständig anaeroben Bedingungen Mikroorganismen isoliert. Während der dreijährigen Studie wurden immer nur kleine Populationen $(\leq 8,0$ koloniebildende Einheiten pro Darmkanal) einer begrenzten Anzahl Bakterienarten isoliert, vor allem die fakultativ anaeroben Arten Paenibacillus macerans, Bacillus licheniformes, B. brevis, B. mycoides und P. polymyxa. Mit Ausnahme der drei Isolate von Clostridium longisporum, die nur im Jahr 1993 gefunden wurden, gab es keine obligaten anaerobe Bakterien. Aus der geringen Größe der Populationen und der Ungleichmäßigkeit der Funde der Bakterien in den verschiedenen Jahren läßt sich schließen, da $\beta$ es nur eine geringe Verbreitung anaerober Mikroorganismen im Magendarmkanal von $M$. rotundata gibt. Entsprechend können sie weder eine große Auswirkung auf die Bedingungen im Darmkanal ausüben noch Einflu $\beta$ auf die Entwicklung der Kalkbrut haben, die durch den insektenpathogenen Pilz Ascosphaera aggregata hervorgerufen wird. (C) Inra/DIB/AGIB/Elsevier, Paris

\section{Megachile rotundata / Larven / Magen- darmkanal / anaerobe}

\section{REFERENCES}

(1) Bae H.D., McAllister T.A., Yanke J., Cheng K.-J., Muir A.D., Effects of condensed tannins on endoglucanase activity and filter paper digestion by Fibrobacter succinogenes $\$ 85$, Appl. Environ. Microbiol. 59 (1993) 2132-2138.

[2] Bryant M.P., Burkey L.A., Cultural methods and some characteristics of some of the more numerous groups of bacteria in the bovine rumen, $\mathrm{J}$. Dairy Sci. 36 ( 1953 ) 205-217.

[3] Dillon R.J., Charnley A.K., Inhibition of Metarhizium anisopliate by the gut bacterial flora of the desert locust: characterisation of antifungal toxins, Can. J. Microbiol. 34 (1988) 1075-1082.

[4] Gilliam M., Taber S., Diseases, pests, and normal microflora of honeybees, Apis mellifera, from feral colonies, J. Invertebr. Pathol. 58 (1991) 286-289.

[5] Gilliam M., Valentine D.K., Bacteria isolated from the intestinal contents of foraging worker honey bees, Apis mellifera: the genus Bacillus. J. Invertebr. Pathol. 28 (1976) 275-276.

[6] Gordon RE, Haynes WC., Pang CH., The Genus Bacillus, USDA Handbook, 1973, p. 427.

[7] Greenberg B., Kowalski J.A., Klowden M.J., Factors affecting the transmission of Salmonella by flies: Natural resistance to colonization and bacterial interference, Infect. Immun. 2 (1970) $800-809$.

[8] Inglis G.D., Goettel M.S., Sigler L., Analysis of alfalfa leafcutter bee (Megachile rotundata) provisions pre- and post-sterilization with propylene oxide, Apidologie 23 (1992) 119-132.

[9] Inglis G.D., Sigler L., Goettel M.S., Trichosporonoides megachiliensis, a new Hyphomycete associated with alfalfa leafcutter bees, with notes on Trichosporonoides and Moniliella, Mycologia 84 (1992) 555-570. 
[10] Inglis G.D., Sigler L., Goettel M.S., Aerobic microorganisms associated with alfalfa leafcutter bees (Megachile rotundata), Microb. Ecol. 26 (1993) 125-143.

[11] Inglis G.D., Goettel M.S., Sigler L., Influence of microorganisms on alfalfa leafcutter bee ( $\mathrm{Mega}$ chile rotundata) larval development and susceptibility to Ascosphaera aggregata, J. Invertebr. Pathol. 61 (1993) 236-243.

[12] Kish L.P., Spore germination of Ascosphaera spp. associated with the alfalfa leafcutting bee, Megachile rotundata, J. Invertebr. Pathol. 36 (1980) 125-128.

[13] Logan N.A., Berkeley R.C.W., Identification of Bacillus strains using the API system, J. Gen. Microbiol. 130 (1984) 1871-1882.
[14] Sasser M., Identification of bacteria through fatty acid analysis, in: Klement Z. (Ed.), Methods in Plant Bacteriology, Akademiai Kiado, Budapest, 1990, pp. 199-204.

[15] Vandenberg J.D., Stephen W.P., Pathogenesis of chalkbrood in the alfalfa leafcutting bee, Megachile rotundata, Apidologie 14 (1983) 333-341.

[16] Vandenberg J.D., Stephen W.P., Conditions of $\mathrm{pH}$ and oxidation-reduction potential in larvae of Megachile rotundata (Fabricius), J. Apic. Res. 23 (1984) 177-180.

[17] Whitfield G.H., Richards K.W, Kveder T.M., Number of instars of larvae of the alfalfa leafcutter bee, Megachile rotundata (F.) (Hymenoptera: Megachilidae), Can. Entomol. 119 (1987) 859-865. 